\title{
Water absorption properties of some tropical timber species
}

\author{
Emmanuel Tete Okoh \\ Department of Furniture Design and Production, Accra Polytechnic, P O Box GP 561, Accra, Ghana
}

Email address:

etokoh@apoly.edu.gh

To cite this article:

Emmanuel Tete Okoh. Water Absorption Properties of Some Tropical Timber Species. Journal of Energy and Natural Resources. Vol. 3, No. 2, 2014, pp. 20-24. doi: 10.11648/j.jenr.20140302.12

\begin{abstract}
The water absorption characteristics during soaking of Terminalia superba ( Ofram), Terminalia ivorensis (Emere) as currently threatened timber species and Quassia undulata (Hotrohotro) and Recinodendron heudelotii.(Wama) as lesser used timber species were studied to determine and compare their absorption and diffusion coefficients as potential substitutes for utilization. Water soaking was carried out for nineteen days and the data were fitted into the Fick's model to determine both the water absorption and diffusion coefficients. The study showed that, the mean values of the water absorption coefficient at initial stages of moisture sorption for Hortrohotro, Ofram, Emere and Wama were 3.51x 10 $0^{-3}$, $4.31 \times 10^{-3}, 1.67 \times 10^{-3}$ and $8.27 \times 10^{-4}\left(\mathrm{~kg} / \mathrm{m}^{2} / \mathrm{s}\right)$ respectively. The corresponding mean values of this parameter for the entire soaking process were also determined for the timber species viz; Ofram $\left(2.91 \times 10^{-3}\right)$, Hortrohotro $\left(2.58 \times 10^{-3}\right)$, Emere $(1.14 \mathrm{x}$ $\left.10^{-3}\right)$ and Wama $\left(6.11 \times 10^{-4}\right) \mathrm{kg} / \mathrm{m}^{2} \mathrm{~s}$ respectively. The measured diffusion coefficient for Wama, Emere, Ofram and Hotrohotro timber species were $9.637 \times 10,^{-4} 6.694 \times 10^{-3} 4.185 \times 10^{-2}$ and $2.899 \times 10^{-2} \mathrm{~kg} / \mathrm{m}^{2} / \mathrm{s}$ respectively. Emere and Wama had lower absorption and diffusion characteristics than Hortrohotro and Ofram. Based on this study, Wama could be substituted for Emere and Hortrohotro with Ofram.
\end{abstract}

Keywords: Absorption, Diffusion, Fick’s Law, Sorption

\section{Introduction}

[1], reported two types of liquid movement in wood: diffusion through the cell walls and flow in the cell lumens. The latter is considerably more prevalent during wood processing. The anatomical features affect non-steady liquid flow in radial and longitudinal directions. The wetting rate through capillary action is much faster than that through diffusion; therefore, the present study aimed to observe free liquid soaking through capillary and diffusion action only.

Although fiber often constitutes the majority of woody tissue, general fiber is not considered as important as vessels in primary liquid flow [2]. However, fiber permeability may influence the subsequent spreading of liquid from vessels or other cells connecting them to pits. Comparing fibers to vessels, non perforated ones are thick walled with relatively small pits that are not adapted for efficient liquid conduction. Apart from this, interconnecting pits provide one of the main pathways for the flow of liquid between cells, and their structure and distribution affects the penetration of liquid in wood [3]. Also, the air that is compressed during liquid penetration lowers the permeability of wood [4]. For this [5], reported that air is compressed during water soaking and additional counter pressure is formed that substantially reduces permeability.

Knowledge of the capillary system is very important for studying the movement of fluids and vapors through a porous material. This fact influences its sorption properties, especially at high relative humidity $(\mathrm{RH})$, where equilibrium is mainly controlled by the capillary forces and consequently by the microstructure of wood species. The capillary system of wood consists of cavities interconnected by narrow channels. The variation in dimensions between the different types of cavities connected in series suggests that desorption tends to be governed by a lower water potential, which is determined by the narrower sections of the pores. In contrast, adsorption tends to be governed by a higher water potential, which depends on the larger sections of the pores; thus, the desorption isotherm will depend on the size of channels connecting the lumina, whereas the adsorption isotherm will depend on the size of these lumina [6]. The permeability of wood is strongly dependent on its moisture content [7], as well as the principal direction of the grain [8] and various physical and chemical properties [9]. 
In exterior applications, the wood-moisture content fluctuates roughly between 8 and 40\% (mass) which causes dimensional changes between 2 to $10 \%$ depending on wood species [10]. The physical processes that control the uptake and release of moisture are: adsorption of water to the hydroxyl groups in the cell walls, diffusion of water molecules through the air inside the wood or the cell wall and capillary flow of liquid water into the pores of wood. Logically, the last process is only involved in the uptake of water as a liquid [11].

Wood is a heterogeneous material and wood pore structure varies greatly among species, logs, and different parts within the same log, resulting in large differences in location and quantity of the penetrated resin. [12] observed that the resin penetration was greater in the early wood than in the latewood. Penetration of UF adhesive in the tangential direction was greater than in the radial direction for beech veneer [13]. The water-swollen wood cell wall contains water amounting to $30 \%$ or more of its dry weight[14]. This might be expected to make the cell wall permeable to water and therefore to provide an alternative to the pathway through the pits for water flowing between adjacent wood cell cavities. The bulk of the axial flow of water in the living tree is known to pass through the pits, but the cell wall pathway could be important when pit closure has occurred or when pits are absent [15].

Wood is biologically degraded in exposed conditions. The uptake of moisture by wood above the fiber saturation point is responsible for wood-decaying fungi to germinate and grow[16]. Another disadvantage is that an increased wood's ability to absorb moisture, affect dimensional stability of wooden materials in service. The uptake and release of moisture and the subsequent changes in dimensions are involved almost in all physical and biological degradation process of the wood and strongly influence the degradation of the coating as well.

Wood in storage is exposed to both periodic water absorption and desorption processes. The water absorption by wood frequently assumes great importance, especially in the structural uses of wood [17]. In residential buildings and in industrial applications, some components are often wood or wood-based [18]. These components are exposed to liquid water, for example wetting by rain or by water infiltration. Thus, wood is always undergoing changes in moisture content. Understanding water absorption by wood during soaking is of practical importance, since it affects the mechanical properties of the product. The effects of moisture content on the mechanical properties of wood have been the subject of an intense investigation worldwide [19]. All strength properties decrease as wood adsorbs moisture in the hygroscopic range. Important properties such as modulus of rupture and compressive strength parallel to grain may decrease up to 4 and 6 percent, respectively, for each percent increase in moisture content [20]. The periodic water absorption has also a negative effect on wood quality. The ability of microorganisms to attack wood depends on the moisture content of the wood cell wall [21]. Hence evaluating water transfer in wood during soaking has attracted considerable attention. The amount of absorbed water in wood is dependent on the density and water diffusivity of wood. The water diffusivity coefficient describes the rate at which water moves from surface to the interior of products. These effects are caused by the porous structure of wood and the reactivity of its chemical components

The current well known primary timber species in Ghana have been exploited selectively by millers, but mostly without permission by illegal chain saw operators, resulting in their reduction both in number and quantum of each of them and the urgent need for finding suitable alternatives for use by both local and the export industry.

Furthermore, there is also ample evidence that timber production in Ghana is not proportional to its potential. Because, its under-utilization is partly as a result of the lack of general information about the wood properties and the great number of timber species. Consequently, Terminalia superba ( Ofram) and Terminalia ivorensis (Emere), as currently threatened timber species and Quassis undulata (Hotrohotro) and Recinodendron heudelotii (Wama) as lesser used timber species were selected for the study to determine and compare their water absorption and diffusion characteristics. Knowledge of moisture uptake and transport properties are essential for predicting the moisture content and utilization of wood.

The primary objective of this research was to measure and compare the water absorption and diffusion coefficients of the four tropical timber species.

\section{Materials and Methods}

Four wood species were selected for the experiments: Wood samples were cut with dimensions $\mathrm{L} \times \mathrm{W} \times \mathrm{T}=70 \times$ $50 \times 35 \mathrm{~mm}^{3}$. The initial moisture content of samples was $0 \%$. Water absorption data were obtained by placing the wood samples between screw-clamps and immersed in a water bath. Experiments were conducted at $25^{\circ} \mathrm{C}$ and for immersion periods, from several minutes to 19 days. After soaking, the moisture content of samples was calculated based on the increase in the sample weight at corresponding times. For this purpose, at regular time intervals, ranging from 60 mins at the beginning to 12 hours during the last stages of the process, the samples were rapidly removed from the water bath and superficially dried with filter paper to eliminate the surface water. The samples were then weighed to determine the moisture uptake. The samples were subsequently returned into water, and the process was repeated until the moisture content attained a range of $109-115 \%$. Five experiments were conducted for each wood species and the mean results were used for further analysis. Finally, curves showing the cumulative weight gain versus the square root of time were plotted, and linear regression curves were computed for each wood sample. The water absorption coefficient of the wood samples was determined by using the following equation [22]

$$
\mathrm{M}_{\mathrm{w}}=\mathrm{A} \sqrt{\mathrm{t}}_{\mathrm{t}}
$$


where, $\mathrm{m}_{\mathrm{w}}$ is the amount of water absorbed in $\mathrm{kg} / \mathrm{m}^{2}$, and $\mathrm{A}$ is the water absorption coefficient $\left(\mathrm{kg} / \mathrm{m}^{2} \mathrm{~s} / 2\right)$. Following the definition, the water absorption coefficient $\mathrm{A}$ is given by the slope of the fitted curve divided by the contact area.

In this study, the Fick's second law of diffusion was used to determine the diffusion coefficients of water in the wood samples. It has been demonstrated that for a short period of soaking time, the following mathematical model may be used to correlate the water uptake ratio (Mt-Mo)/(Ms-Mo) with diffusion of water in solids of arbitrary shape during soaking in water [23]

$$
\frac{\text { Mt-Mo }}{\text { Ms-Mo }}=2 / \sqrt{\pi}\left(\frac{s}{V}\right) \sqrt{D_{e} t}=\left(\alpha_{b}\right)^{2}
$$

where, Ms and Mo are constants for wood samples, depending on the physical properties, and the ratio of volume-to-surface area $(\mathrm{V} / \mathrm{S})$ may be taken as constant, irrespective of moisture content. To determine the diffusion coefficient, data were plotted as water uptake data against the square root of time, $t$. If the initial part of the curve was linear, it would be possible to determine its slope, $\alpha_{b}$, and the coefficient of diffusion, $D_{e}$, by the following relation:

$$
\mathrm{D}_{\mathrm{e}=} \frac{\pi}{4}\left(\frac{\mathrm{V}}{\mathrm{S}}\right)^{2}\left(\alpha_{\mathrm{b}}\right)^{2}
$$

\section{Results and Observations}

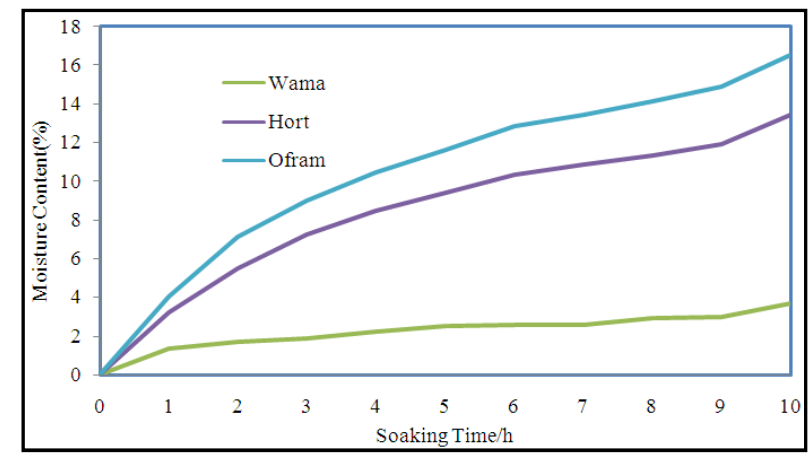

Figure 1a. Water absorption graphs during initial soaking of timber species in plain water.

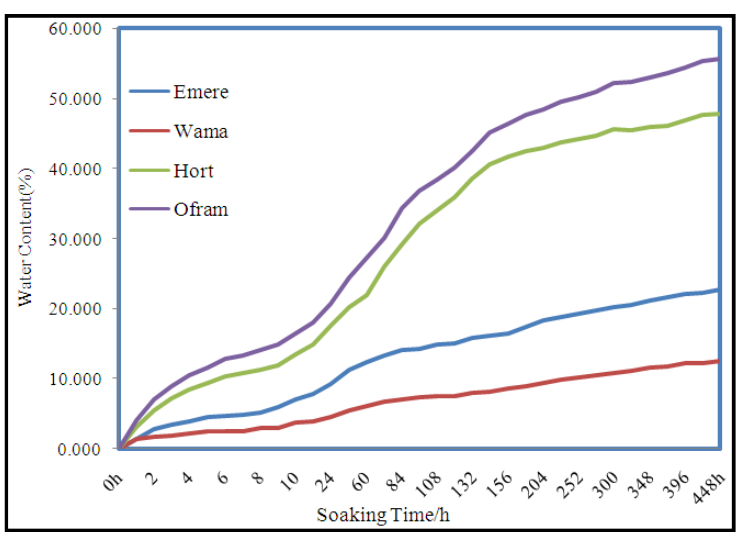

Figure 1b. Water absorption graphs during the entire soaking period of timber species in plain water.

Figure 1a shows the initial water absorption curves for a period of ten hours by the timber species in plain water. By the end of the tenth hour, Ofram had absorbed 16.512 percent of moisture followed by Hortrohotro with 13.448 percent of moisture. During the same absorption period under review, Emere and Wama absorbed 7.05 and 3.70 percent moisture respectively. It is clear from the figure 1 that, both Ofram and Hotrohotro had high initial uptake of moisture Emere and Wama.

Figure $1 \mathrm{~b}$ shows the entire water absorption curves for a period of nineteen days of soaking of the timber species in plain water. By the end of the nineteenth day, Ofram had absorbed 55.733 percent of moisture followed by Hortrohotro with 47.802 percent of moisture. Emere and Wama absorbed 22.796 and 12.545 percent moisture respectively. It can be noted that for the entire soaking period of nineteen days (figure 1b), both Ofram and Hotrohotro had the highest uptake of moisture as compared to Emere and Wama.

Figure 2 a displays the variation in the initial amount of water absorbed against soaking time of the timber species. After four hours of initial soaking, the water absorption coefficients of the timber species were determined according to equation 1 . The mean values of the water absorption coefficient (A) at initial stages of moisture sorption for Hortrohotro, Ofram, Emere and Wama were $3.51 \times 10^{-3}$, $4.31 \times 10^{-3}, 1.67 \times 10^{-3}$ and $8.27 \times 10^{-4}\left(\mathrm{~kg} / \mathrm{m}^{2} / \mathrm{s}\right)$ respectively. The corresponding mean values of this parameter for the entire soaking process were determined for the timber species viz; Ofram $\left(2.91 \times 10^{-3}\right)$, Hortrohotro $\left(2.58 \times 10^{-3}\right)$, Emere $\left(1.14 \times 10^{-3}\right)$ and Wama $\left(6.11 \times 10^{-4}\right) \mathrm{kg} / \mathrm{m}^{2} \mathrm{~s}$ and are shown in Fig. $2 b$.

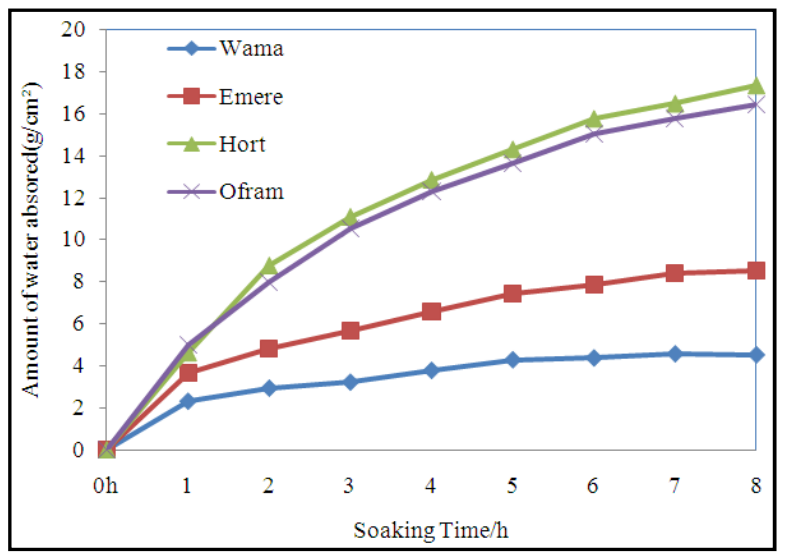

Figure 2a. Variation in the initial amount of water absorbed against soaking time of the timber species.

The corresponding mean values of this parameter for the entire soaking process were determined for the timber species viz; Ofram $\left(2.91 \times 10^{-3}\right)$, Hortrohotro $\left(2.58 \times 10^{-3}\right)$, Emere $\left(1.14 \times 10^{-3}\right)$ and Wama $\left(6.11 \times 10^{-4}\right) \mathrm{kg} / \mathrm{m}^{2} \mathrm{~s}$ and are shown in Fig. $2 b$.

Similarly, the diffusion coefficient (De) of the timber species were also determined. This diffusion coefficient (De) was calculated after neglecting the non-Fickian behaviour and using the slope, the absorption data was fitted into equation 3 after the initial period of soaking. The measured 
diffusion coefficient(De) for Wama, Emere, Ofram and Hotrohotro timber species were $9.637 \times 10^{-4}, 6.694 \times 10^{-3}$, $4.185 \times 10^{-2}$ and $2.899 \times 10^{-2} \mathrm{~kg} / \mathrm{m}^{2} / \mathrm{s}$ respectively.

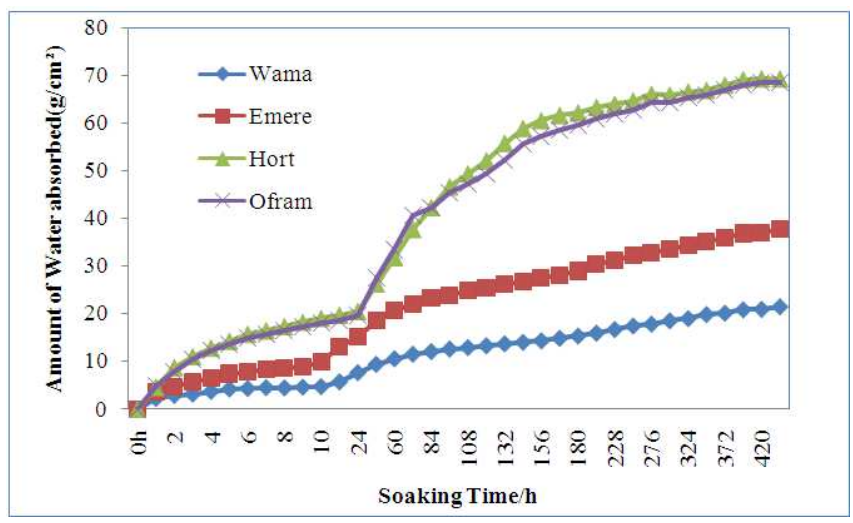

Figure 2b. Variation in the amount of water absorbed during the entire soaking process of the timber species.

\section{Discussion}

The timber species showed an initial rate of high moisture uptake (Fig. 2a) followed by slower absorption in the later stages, also known as the relaxation phase [24]. The nature of water vapour uptake indicates a two-stage process, in which Ofram and Hotrohotro absorbed $29 \%$ and $27 \%$ of the total moisture content during the initial 10 hour period (Figure 1a). This was followed by a period of very slow but ongoing water vapour uptake. The moisture content absorbed by the timber species over the entire soaking period of 19 days stood at $56 \%$ and $48 \%$ respectively for Ofram and Hortrohotro (Figure 1b). [25] measured a similar value of $56.78 \%$ moisture content for a hardwood species from Iran. Emere and Wama reached 31\% and 30\% of moisture content after 10 hours of soaking as against the entire soaking period's values of $23 \%$ and $13 \%$ respectively. It can be inferred from this study that, although Ofram and Hotrohotro had an overall higher moisture uptake over the entire soaking period, Emere and Wama's initial moisture uptake values of 31 and $30 \%$ exceeded that of $O$ fram and Hotrohotro i.e. $29 \%$ and $27 \%$ respectively. This absorption phenomenon can be explained by the presence of capillaries present in wood, which quickly reaches equilibrium with the hydration medium by capillary action. During the early stages of the water absorption process, capillaries and cavities near the surface are filled quickly. Consequently, the water concentration at the surface is raised to saturation level almost instantaneously. The moisture gradient is limited to the inside of the material exclusively. Large wood cell cavities aid unrestricted water flow, but in the small ones, the presence of trapped air bubbles control the interior water gradient. Water absorption measurement is important because of the structural uses of wood [27]. Wood components in residential buildings and industrial applications are periodically exposed to liquid water in the form of rain or water vapour. An increase in 2 or $3 \%$ of water vapour can cause reduction in strength properties of timber structures [28]. Also wood is attacked by microorganisms when the moisture content exceeds the fiber saturation point (FSP). This FSP is between 27 to $30 \%$ of moisture content. In this study Emere and Wama reached moisture content values of 23 and $13 \%$ respectively during the entire soaking period of 19 days. These moisture content values were far below the FSP of these timber species for any structural deformation and microbial attack to occur. However, Hotrohotro and Ofram reached in excess of 48 and $56 \%$ respectively of moisture content which were above the FSP during the same period of soaking. Hotrohotro and Ofram can be used outside only by subjecting them to some form of surface treatments to prevent them from infiltration of rain and water vapour as well as fungal attack. For a prolong exterior utilization of any of these timbers, it will be advisable to apply some form of surface treatments to protect them from structural and microbial damage.

The diffusion coefficient(De) measured for Wama $\left(9.637 \times 10^{-4} \mathrm{~m}^{2} / \mathrm{s}\right)$ was the lowest among the other timber

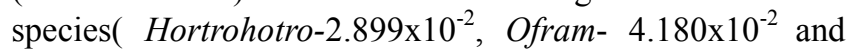
Emere- $6.694 \times 10^{-3} \mathrm{~m}^{2} / \mathrm{s}$ respectively) The amount of absorbed water in wood is also dependent on the density and water diffusivity of wood. In this study Wama $\left(>0.5 \mathrm{~g} / \mathrm{cm}^{3}\right)$ as the densest wood, had the lowest water diffusivity. The water diffusivity coefficient describes the rate at which water moves from surface to the interior of products. These effects are caused by the porous structure of wood and the reactivity of its chemical components. This explains why Wama had the lowest absorption and diffusion rates.

\section{Conclusion}

The study showed that, the mean values of the water absorption coefficient at initial stages of moisture sorption for Hortrohotro, Ofram, Emere and Wama were 3.51x $10^{-3}$, $4.31 \times 10^{-3}, 1.67 \times 10^{-3}$ and $8.27 \times 10^{-4}\left(\mathrm{~kg} / \mathrm{m}^{2} / \mathrm{s}\right)$ respectively. The corresponding mean values of this parameter for the entire soaking process were also determined for the timber species viz; Ofram $\left(2.91 \times 10^{-3}\right)$, Hortrohotro $\left(2.58 \times 10^{-3}\right)$, Emere $\left(1.14 \mathrm{x} 10^{-3}\right)$ and Wama $\left(6.11 \times 10^{-4}\right) \mathrm{kg} / \mathrm{m}^{2} \mathrm{~s}$ respectively. The measured diffusion coefficient for Wama, Emere, Ofram and Hotrohotro timber species were $9.637 \times 10,^{-4} 6.694 \times 10^{-3} 4.185 \times 10^{-2}$ and $2.899 \times 10^{-2} \mathrm{~kg} / \mathrm{m}^{2} / \mathrm{s}$ respectively. Emere and Wama had a lower absorption and diffusion characteristics than Hortrohotro and Ofram. Based on these findings, Wama could be substituted for Emere and Hortrohotro with Ofram.

\section{References}

[1] U. Watanabe, Y. Imamura and I. Iida, Liquid penetration of pre-compressed wood VI: Anatomical characterization of pit fractures. J. Wood Sci. 44: 158-162, 1998.

[2] S. Leal, V.B. Sousa, and H. Pereira., Radial variation of vessel size and distribution in cork oak wood (Quercus suber L.). Wood Sci. Technol. 41: 339-350, 2007. 
[3] Y. Sano, Intervascular pitting across the annual ring boundary in Betula platyphylla var. japonica and Fraxinus mandshurica var. japonica. IAWA J. 25: 129 140, 2004.

[4] J. Virta,, S. Koponen and I. Absetz., Modeling moisture distribution in wooden cladding board as a result of short-term single-sided water soaking. Building Environ. 41: 1593-1599, 2006.

[5] W.B. Banks, Some factors affecting the permeability of Scots pine and Norway spruce. J. Inst. Wood Sci. 5, $10-17,1970$.

[6] Y. FortinMoisture content-matric potential relationship and water flow properties of wood at high moisture contents. PhD thesis, University of British Columbia, Vancouver. 1979 Strømdahl, K., (2000). Water sorption in wood and plant fibres (Series R, No. 78). Department of Structural Engineering and Materials, Technical University of Denmark

[7] C. Hansmann,, Gindl, W., Wimmer, R. and Teischinger, A., Permeability of wood - a review. Wood Res. Drevarsky Vysk. 47, $1-16,2002$.

[8] G. Bramhall, The validity of Darcy's Law in the axial penetration of wood. Wood Sci. Technol. 7, 319-322, 1971.

[9] A.B. Wardrop, and Davies, G.W., Morphological factors relating to the penetration of liquids into wood. Holzforschung 15, 129 - 141, 1961.

[10] T. Rypstra, Analytical techniques for the evaluation of wood and wood fi nishes during weathering, Ph.D. Thesis, University of Stellenbosch, 1995. and Rijsdijk,J.F, P.B., Laming, (1994). Physical and related properties of 145 timbers, Kluwer Academic Publishers, Dordrecht

[11] C. F Siau, Wood: Influence of moisture on physical properties. Blacksburg, Virginia Polytechnic Institute and State University, 1995.

[12] L.A. Smith, and W. A. Cote., Studies of penetration of phenol-formaldehyde adhesive into beech wood. Wood Fiber Sci. 3(1):56-57, 1971.

[13] M. Sernek, J. Resnik, and F. A. Kamke, Penetration of liquid urea-formaldehyde adhesive into beech wood. Wood Fiber Sci. 31(1):41-48, 1999.

[14] C. Skaar, Water in wood. Syracuse University Press, 1972. Syracuse, N.Y.
[15] R. D. Preston, The physical biology of plant cell walls. 1974, Chapman and Hall, London

[16] A. Eckeveld van, Homan, W.J. and Militz, H., Increasing the water repellency of Scots pine sapwood by impregnation with undiluted linseed oil, wood oil, coccos oil and tall oil. Holzforsch. Holzverwert. 53, 113 - 115, 2001.

[17] R. Baronas, Ivanauskas F., Juodeikienė I., Kajalavicius A.,Modelling of Moisture Movement in Wood during Outdoor Storage. Nonlinear Analysis: Modelling and Control, 2, 3-1, 2001.

[18] L. Candanedo, Derome, D., - Numerical simulation of water absorption in softwood. Ninth International IBPSA Conference, 2005. Montréal, Canada

[19] C.C. Gerhards, - Effect of moisture content and temperature on the mechanical properties of Wood: an analysis of immediate effects. Wood and Fiber Science, 14, 154-163,1998. Obataya, E, Norimoto, M, Gril, J., (1998) The effects of adsorbed water on dynamic mechanical properties of wood. Polymer, 39(14), 3059-3064 and Severa L., Buchar J., Krivanek I., (2003) - The influence of the moisture content on the fracture of the notched wood beam. 8th International IUFRO Wood Drying.

[20] B.A. Bendtsen, - Sorption and swelling characteristics of salt-treated wood. U. S. Forest Service Research Paper FPL 60, 1966.

[21] R. Baronas, Ivanauskas F., Juodeikienė I., Kajalavicius A.,Modelling of Moisture Movement in Wood during Outdoor Storage. Nonlinear Analysis: Modelling and Control, 2, 3-1, 2001 .

[22] M. Krus. Moisture Transport and Storage Coefficients of Porous Mineral Building Materials. Theoretical Principles and New Test Methods,1996. Fraunhofer IRB Verlag. Germany, 106 p. plus appendix

[23] N.E. Marcovich, M.M. Reboredo, M.I. Aranguren, Moisture diffusion in polyester- wood flour composites. Polymer 40, 7313-7320, 1999.

[24] A. Kumar, P.C., Flynn - Uptake of fluids by boreal wood chips: Implications for bioenergy. Fuel Processing Technology 87, 605-608, 2006.

[25] J. Khazaei, Water absorption in three wood varieties. Cercetări Agronomice în Moldova,2008.Vol. XLI , No. 2 (134). 